\title{
Growth in Farming Population and Land Depletion and Deforestation in Rural Communities of Cross River State: The Case of Obubra Local Government Area, Nigeria
}

\author{
Enang, Ebingha Erena (Ph.D) \\ Department of Sociology, University of Calabar, \\ Calabar, Cross River State, Nigeria \\ Email: enangebingha@yahoo.com,08037162984
}

Doi:10.5901/jesr.2013.v3n2p231

\begin{abstract}
The purpose of this paper is to examine the relationship between growth in farming population and land depletion and deforestation among rural communities in the context of Nigeria society, using Obubra in CrossRiverState as a case study. Relevant literature was reviewed to put the issue in proper light, while a sample of five hundred and twelve (512) was used to gather data and the linear regression analysis to test the relationship. The findings and implications of the study reveal Nigeria and Obubra Local Government Area in particular are still lagging in agricultural transformation and forest preservations because of the growth in farming population. The practical implications is that an understanding of the current threat can help policy makers in the country pursue new agricultural techniques for rural farmers on the one hand, and would be of importance for the growing youthful population to accept agriculture for Nigeria's economic future success on the other.
\end{abstract}

Keywords: Farming, Population, Land depletion, Deforestation

\section{Introduction}

The relationship that exists between population dynamics and the resources necessary to sustain human existence has occupied an important position since the beginning of population studies. Although Malthusian ideas that population would outnumber food production have been heavily criticized because technological development has made increase in productivity possible, the problem of the discrepancy between population size and means of subsistence still remains an issue of concern to both developed and developing countries of the world (Orubuloye and Oyeneye, 1983).

The basic concern of development planning in Nigeria include the provision of education, health, better nutritional facilities for the masses, reduction in unemployment and under-employment, a rise in the standard of living, provision of food in sufficient quantity and quality etc. As expected, resources are needed to achieve the above planning goals. Thus the consequence of population growth and change require that resources which could be used for development must be allocated in line with increased population and at the same time ensure that conflict, which might arise in distribution, is eliminated and poverty brought under control. In other words, increase in population compete directly for resources that would raise income and standard of living (Olusanya and Pursell, 1981).

The idea is not new that behaviour is influenced by the interplay between aspirations and the resources people have to satisfy their aspirations (Easterlin, 1976). If the resources were unlimited, there would be a chance to avoid conflict. The very phenomenon of population growth on our finite planet, however, implies competition which only creates circumstances conducive to conflict between individuals and groups.

For a short time in history, it seemed, at least in Obubra, as if man had finally mastered the fundamental problem of resource (land) development, and was entering a long era of abundance. Now, the Obubra people seem to be approaching the era of land scarcity due to increase in population as individuals and groups either strive to maintain their land or extend their boundaries, hence there is conflict. 
In the emerging scenario, two kinds of participants can be seen here: those who have land and those who do not have but have labour to supply. In the past, the dices were heavily in favour of the former as the latter were economically dependent on them. With the increase in population, the two groups are now opposed to one another resulting from land scarcity. Considering all these factors, the study attempts to examine growth in farming population with emphasis on land depletion resulting from the unavailability of land to meet up with its challenges

\section{Literature Review}

Environmental depletion or degradation and population movements have been noted in nearly all countries of the world, despite the fact that the phenomenon is highly studied nationally. Many countries find themselves handicapped in their economic growth by the degradation of their environment, the physical surroundings in which the population lives. Barber (1989) notes "Africa must grapple with two major trends, explosive population growth and accelerating environmental degradation. He further states that the depletion of the environment in Africa has both domestic and international dimensions. Unless halted, it threatens the productive base in Africa. Also contributing, Hinrichsen (1990) asserts that despite the declining population growth rates, an increasing number of people each year will continue to exert pressure on land and other resources well after close of the twenty-first century. He argued further that more than 93 percent of population growth is taking place in developing countries that are least equipped to meet the resource demands of rapidly expanding populations. It has also been noted that African countries (Nigeria inclusive) where the rate of population growth exceeds the rate of economic growth, there is the inability of African countries to generate the wealth needed to absorb all people in a society that guarantees a basic level of existence for all. As a result, the natural resource base is often overexploited to compensate for a lack of other resources (Population Reference Bureau, 1991). Sfeir-Younis (1986) also opined that the chief form of land degradation is soil erosion. Unchecked soil erosion could well cause a decline of from 19 to 29 percent in food production from rainfall croplands. And that agricultural yields are expected to meet the demands of population growth in the short term, while at a cost to soil cover and fertility that eventually leads to a decline in crop productivity.

On the other hand, loss of forest has been extensive in Nigeria as much of the wood goes for household cooking as nine of every ten (10) African households burn wood for cooking (Barnes, 1990). The forest loss is closely related to the increase in farming population as most households cannot afford other fuels, demand for wood - and cleared land for agriculture - is likely to continue rising for several decades. Rudel (1989) in his study of the relationship between farming population growth and tropical deforestation in thirty-six (36) developing countries between 1970 and 1980, found a correlation between fuel-wood use and land clearing major causes of deforestation; these findings were also corroborated by George, M. E. (1991).

Several situations have stressed the symbolic relationship between man's expanded socio-economic activities and the environment. Meadows et al (1972) are of the opinion that man's continued excessive use of the natural resource, especially wood, may deplete and eventually exhaust them. This pessimism was shared by Arnold (1983) and Oseni (1983) when they stressed the adverse consequences of excessive fuel-wood consumption on the environment through deforestation.

In essence, the continued increase in the prices of fuel-wood substitutes, coupled with the low percentage of rural electrification in Nigeria, has accentuated the consumption of fuel wood in the economy with its adverse effect on the environment. Moreover, the rapid population growth, coupled with the rural-urban migration that makes many towns more ruralized has further threatened the environment.

\section{Methodology and Analysis of Data}

Being a sample survey, data were collected from randomly selected villages from the four clans of Obubra, viz; Adun, Okum, Osopong and Ofonbongha - Yala. The study participants consist of illiterates and semi-literate groups who are permanently engaged in farming and farm-related activities. The survey instrument was the questionnaire which sought information on respondents' age, sex, marital status, occupation, land depletion and communal conflict. The bias for rural communities of Obubra was informed by the fact that their source of livelihood is mostly subsistence agriculture which is dependent on land availability and sustenance. A multi- 
stage sampling technique was used to arrive at a representative sample of respondents. 512 questionnaires were retrieved from the 553 administered. This is because the number of respondents in each clan was determined by its population.

Data collected were analyzed using frequency distribution and linear regression analysis.

\section{Hypothesis}

$\mathrm{H}_{0}$ : Growth in farming population has no significant relationship with land depletion.

$\mathrm{H}_{1}$ : Growth in farming population has a significant relationship with land depletion.

$X$ (independent): Growth in farming population

$Y$ (dependent): Land depletion and deforestation

Table 1: Distribution of respondents by age

\begin{tabular}{|c|c|c|c|c|c|c|c|c|c|c|}
\hline \multirow{3}{*}{ AGE } & \multicolumn{10}{|l|}{ CLAN } \\
\hline & \multicolumn{2}{|c|}{ ADUN } & \multicolumn{2}{|c|}{ OKUM } & \multicolumn{2}{|c|}{ OFUMBONGHA } & \multicolumn{2}{|c|}{ OSOPONG } & \multicolumn{2}{|c|}{ TOTAL } \\
\hline & Freq. & (\%) & Freq. & (\%) & Freq. & (\%) & Freq. & $(\%)$ & Freq. & (\%) \\
\hline $18-22$ & 13 & $2.54 \%$ & 12 & $2.34 \%$ & 4 & $0.78 \%$ & 11 & $2.15 \%$ & 40 & $7.81 \%$ \\
\hline $23-27$ & 38 & $7.42 \%$ & 33 & $6.45 \%$ & 12 & $2.34 \%$ & 31 & $6.05 \%$ & 114 & $22.27 \%$ \\
\hline $28-32$ & 35 & $6.84 \%$ & 30 & $5.86 \%$ & 11 & $2.15 \%$ & 29 & $5.66 \%$ & 105 & $20.51 \%$ \\
\hline $33-37$ & 37 & $7.23 \%$ & 32 & $6.25 \%$ & 12 & $2.34 \%$ & 30 & $5.86 \%$ & 111 & $21.68 \%$ \\
\hline $38-42$ & 15 & $2.93 \%$ & 13 & $2.54 \%$ & 6 & $1.17 \%$ & 12 & $2.34 \%$ & 46 & $8.98 \%$ \\
\hline $43-47$ & 17 & $3.32 \%$ & 14 & $2.73 \%$ & 5 & $0.98 \%$ & 13 & $2.54 \%$ & 49 & $9.57 \%$ \\
\hline $48-52$ & 9 & $1.76 \%$ & 8 & $1.56 \%$ & 2 & $0.39 \%$ & 7 & $1.37 \%$ & 26 & $5.08 \%$ \\
\hline $53-57$ & 4 & $0.78 \%$ & 3 & $0.59 \%$ & 2 & $0.39 \%$ & 3 & $0.59 \%$ & 12 & $2.34 \%$ \\
\hline $58+$ & 3 & $0.59 \%$ & 2 & $0.39 \%$ & 1 & $0.20 \%$ & 3 & $0.59 \%$ & 9 & $1.76 \%$ \\
\hline Total & 171 & $33.40 \%$ & 147 & $28.71 \%$ & 55 & $10.74 \%$ & 139 & $27.15 \%$ & 512 & $100.00 \%$ \\
\hline
\end{tabular}

Source: Fieldwork, 2013

The composition of the age data reflects a high concentration of respondents between the age bracket of $23-37$ as they constitute 64.4 percent of the respondents and present a picture of a youthful population.

Table 2: Distribution of respondents by marital status

\begin{tabular}{|c|c|c|c|c|c|c|c|c|c|c|}
\hline \multirow{3}{*}{ MARITAL STATUS } & \multicolumn{10}{|l|}{ CLAN } \\
\hline & \multicolumn{2}{|c|}{ ADUN } & \multicolumn{2}{|c|}{ OKUM } & \multicolumn{2}{|c|}{ OFUMBONGHA } & \multicolumn{2}{|c|}{ OSOPONG } & \multicolumn{2}{|c|}{ TOTAL } \\
\hline & Freq. & (\%) & Freq. & (\%) & Freq. & (\%) & Freq. & (\%) & Freq. & (\%) \\
\hline Never married & 39 & $7.62 \%$ & 34 & $6.64 \%$ & 13 & $2.54 \%$ & 32 & $6.25 \%$ & 118 & $23.05 \%$ \\
\hline Married (Monogamy) & 45 & $8.79 \%$ & 38 & $7.42 \%$ & 15 & $2.93 \%$ & 37 & $7.23 \%$ & 135 & $26.37 \%$ \\
\hline Married (polygamy) & 66 & $12.89 \%$ & 57 & $11.13 \%$ & 21 & $4.10 \%$ & 53 & $10.35 \%$ & 197 & $38.48 \%$ \\
\hline Divorce & 11 & $2.15 \%$ & 11 & $2.15 \%$ & 3 & $0.59 \%$ & 9 & $1.76 \%$ & 34 & $6.64 \%$ \\
\hline Widowed & 4 & $0.78 \%$ & 3 & $0.59 \%$ & 1 & $0.20 \%$ & 3 & $0.59 \%$ & 11 & $2.15 \%$ \\
\hline Separated & 6 & $1.17 \%$ & 4 & $0.78 \%$ & 2 & $0.39 \%$ & 5 & $0.98 \%$ & 17 & $3.32 \%$ \\
\hline Total & 171 & $33.40 \%$ & 147 & $28.71 \%$ & 55 & $10.74 \%$ & 139 & $27.15 \%$ & 512 & $100.00 \%$ \\
\hline
\end{tabular}

Source: Fieldwork, 2013

The table shows that a greater percentage of the respondents were polygynously married as they constitute 34.48 percent of the total respondents. Specifically, the table shows that monogamy is gradually closing on polygyny, which is cherished by the people because farming needs enough hands especially as it is being dominated by locally made tools and devoid of fertilizer usage. 
Table 3: Distribution of respondents by occupation

\begin{tabular}{|c|c|c|c|c|c|c|c|c|c|c|}
\hline \multirow{3}{*}{ OCCUPATION } & \multicolumn{10}{|l|}{ CLAN } \\
\hline & \multicolumn{2}{|c|}{ ADUN } & \multicolumn{2}{|c|}{ OKUM } & \multicolumn{2}{|c|}{ OFUMBONGHA } & \multicolumn{2}{|c|}{ OSOPONG } & \multicolumn{2}{|c|}{ TOTAL } \\
\hline & Freq. & (\%) & Freq. & (\%) & Freq. & (\%) & Freq. & (\%) & Freq. & (\%) \\
\hline Farming only & 93 & $18.16 \%$ & 79 & $15.43 \%$ & 30 & $5.86 \%$ & 75 & $14.65 \%$ & 277 & $54.10 \%$ \\
\hline ...plus farming & 56 & $10.94 \%$ & 49 & $9.57 \%$ & 18 & $3.52 \%$ & 46 & $8.98 \%$ & 169 & $33.01 \%$ \\
\hline Civil servant only & 7 & $1.37 \%$ & 6 & $1.17 \%$ & 2 & $0.39 \%$ & 5 & $0.98 \%$ & 20 & $3.91 \%$ \\
\hline Private Bus. Only & 3 & $0.59 \%$ & 2 & $0.39 \%$ & 1 & $0.20 \%$ & 2 & $0.39 \%$ & 8 & $1.56 \%$ \\
\hline Factor worker only & 3 & $0.59 \%$ & 1 & $0.20 \%$ & 1 & $0.20 \%$ & 2 & $0.39 \%$ & 7 & $1.37 \%$ \\
\hline Student only & 6 & $1.17 \%$ & 4 & $0.78 \%$ & 2 & $0.39 \%$ & 5 & $0.98 \%$ & 17 & $3.32 \%$ \\
\hline Unemployed only & 3 & $0.59 \%$ & 4 & $0.78 \%$ & 1 & $0.20 \%$ & 3 & $0.59 \%$ & 11 & $2.15 \%$ \\
\hline Others - specified & 0 & $0.00 \%$ & 2 & $0.39 \%$ & 0 & $0.00 \%$ & 1 & $0.20 \%$ & 3 & $0.59 \%$ \\
\hline Total & 171 & $33.40 \%$ & 147 & $28.71 \%$ & 55 & $10.74 \%$ & 139 & $27.15 \%$ & 512 & $100.00 \%$ \\
\hline
\end{tabular}

Source: Fieldwork, 2013

The distribution shows that 87.11 percent of the sample were farmers; 54.10 practice farming, only 33.01 percent combine farming with other economic activities. This is not surprising given the set up in which the research was conducted.

Table 4: Distribution of respondents by acres of land depleted

\begin{tabular}{|c|c|c|c|c|c|c|c|c|c|c|}
\hline \multirow{3}{*}{ ACRES } & \multicolumn{10}{|l|}{ CLAN } \\
\hline & \multicolumn{2}{|l|}{ ADUN } & \multicolumn{2}{|c|}{ OKUM } & \multicolumn{2}{|c|}{ OFUMBONGHA } & \multicolumn{2}{|c|}{ OSOPONG } & \multicolumn{2}{|c|}{ TOTAL } \\
\hline & Freq. & (\%) & Freq. & (\%) & Freq. & (\%) & Freq. & (\%) & Freq. & (\%) \\
\hline $0-5$ & 10 & $16.13 \%$ & 9 & $14.52 \%$ & 4 & $6.45 \%$ & 7 & $11.29 \%$ & 30 & $48.39 \%$ \\
\hline $6-11$ & 9 & $14.52 \%$ & 6 & $9.68 \%$ & 1 & $1.61 \%$ & 4 & $6.45 \%$ & 20 & $32.26 \%$ \\
\hline $12-17$ & 5 & $8.06 \%$ & 2 & $3.23 \%$ & 0 & $0.00 \%$ & 1 & $1.61 \%$ & 8 & $12.90 \% 6$ \\
\hline $18+$ & 3 & $4.84 \%$ & 1 & $1.61 \%$ & 0 & $0.00 \%$ & 0 & $0.00 \%$ & 4 & $45 \%$ \\
\hline Total & 27 & $43.55 \%$ & 18 & $29.04 \%$ & 5 & $8.06 \%$ & 12 & 19.35 & 62 & $100.00 \%$ \\
\hline
\end{tabular}

Source: Fieldwork, 2013

The data shows that respondents across the four clans of Obubra who own $0-5$ acres of land admit that 30 acres (48.39\%) of land has been depleted, while those with 6-11 acres lost 20 acres (32.36\%). It shows that the higher the acres of land owned, the lower the depletion rate and vice-versa.

\section{Discussion of Findings}

Findings revealed that a greater percentage of the respondents fall within the youthful age group with 34.48 percent of them being polygynously married which has implication for future population growth as monogamy is yet to be fully embraced. This is a pointer to the fact that subsistence farming requires enough hands to assist in crop cultivation and harvest.

Similarly, the major occupation of the people was farming as shown in the above table as only a few of them combine farming with other economic activities such as trading, fishing or civil service jobs. The depletion of land was seen to be threatening due to continuous economic activities and exposure to erosion and other human activities. The tested hypothesis shows evidence that variation in land depletion and deforestation is caused by the growth in farming population.

\section{Conclusion}

In conclusion, therefore, it could be said that the increasing number of farmers in Obubra is a serious threat to 
land availability and land depletion as it has been revealed that the smaller the acre of land available, the higher the depletion. Land being a fixed resource and farming population which continues to increase constitutes an economic problem to the present and future population, hence the need to check the growth in farming population through the diversification of the means of livelihood.

\section{References}

Orubuloye, I. O. and Oyeneye, O. Y. (1983) "Population and Development: An Overview" In I. O. Orubuloye and O. Y. Oyeneye (eds) Population and Development in Nigeria (Ibadan: NISER)

Olusanya, P. O. and Pursell, J. (1981) The Prospect of Economic Development in Nigeria under Conditions of Rapid Population Growth. Ibadan: NISER

Easterlin, R. A. (1976) "The Conflict between Aspiration and Resources, in Population and Development Review 1 and 2

Barber, B. C. (1989) "Introduction in Sub-Saharan Africa: From Crisis to Sustainable Growth. Washington D.C. The World Bank

Hinrichsen, D. (1990) Our common sea: Coast in Crisis. London: Earthscan Publishers

Population Reference Bureau (1991) 1991 World Population Data and Policy Intervention Policy and Research Report, No. 8, Washington D.C.: The World Bank

Sfeir-Younis, A. (1986) Soil Conservation in Developing Countries - A Background Report. Washington D.C.: The World Bank

Barnes, D. F. (1990) "Population Growth, Wood Fuel and Resource Problem in Sub-Saharan Africa" Energy Series paper No. 26, Washington D.C.: World Bank, March

Rudel, T. K. (1989) "Population, Development and Tropical Deforestation: A Cross National Study"Rural Sociology, 545: 3

George, M. E. 91991) "Population and the Environment: Cross-Cultural Exploration of Deforestation in Low Income Countries" presented at the Population Association of America meeting, Washington, D.C., March 27

Meadows, Donella H., Dennis Meadows, Jorgan Randers and William W. Behrens (1972) The Limits to Growth: A Report on the Club of Rome's Project on the Predicament of Mankind. New York: Universe

Arnold, J. E. (1983) "Fuel wood and Charcoal in Developing Countries": UNASYLVA

Oseni, A. M. (1983) "World Energy in the Year 2000", paper presented at the Science Association of Nigeria, 27th Annual Conference, Ibadan

\section{Appendix One}

\section{Growth of farming population (X) and land depletion/ deforestation (Y)}

\begin{tabular}{|l|l|l|l|l|}
\hline$Y$ & $X$ & $Y^{2}$ & $X^{2}$ & $X Y$ \\
\hline 27 & 356 & 729 & 126736 & 9612 \\
18 & 345 & 324 & 119025 & 6210 \\
5 & 329 & 25 & 108241 & 1645 \\
12 & 338 & 144 & 114244 & 4056 \\
\hline 62 & 1368 & 122 & 468246 & 21523 \\
$\Sigma Y$ & $\Sigma X$ & $\Sigma Y^{2}$ & $\Sigma X^{2}$ & $\Sigma X Y$ \\
\hline
\end{tabular}

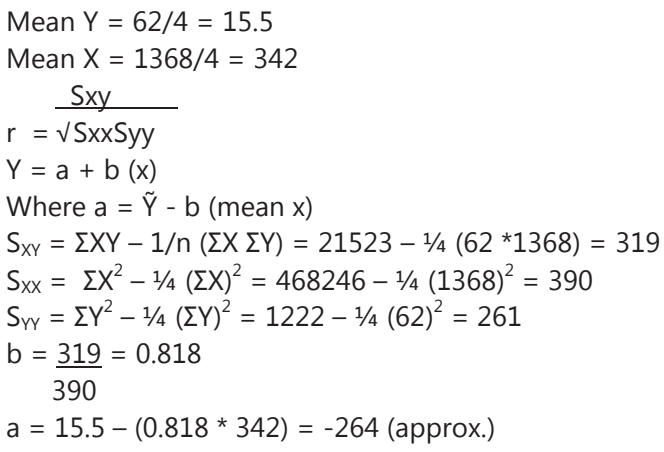


Thus the predictive equation for the relation between population and communal conflicts is $y=-21+$ $0.051(\mathrm{x})$

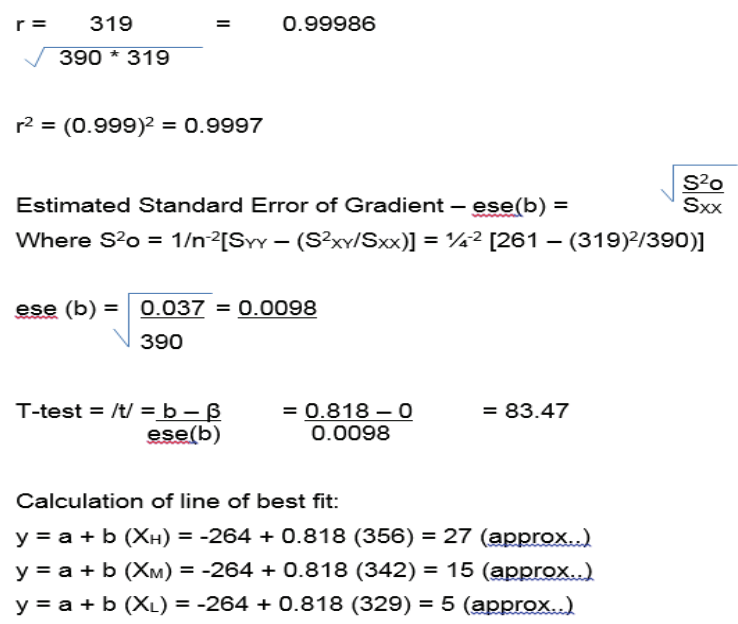

Where $X_{H}, X_{M}$ and $X_{L}$ are the highest, mean and lowest values of population $(X)$ respectively.

The line of best fit is shown graphically as:

\section{Appendix Two}

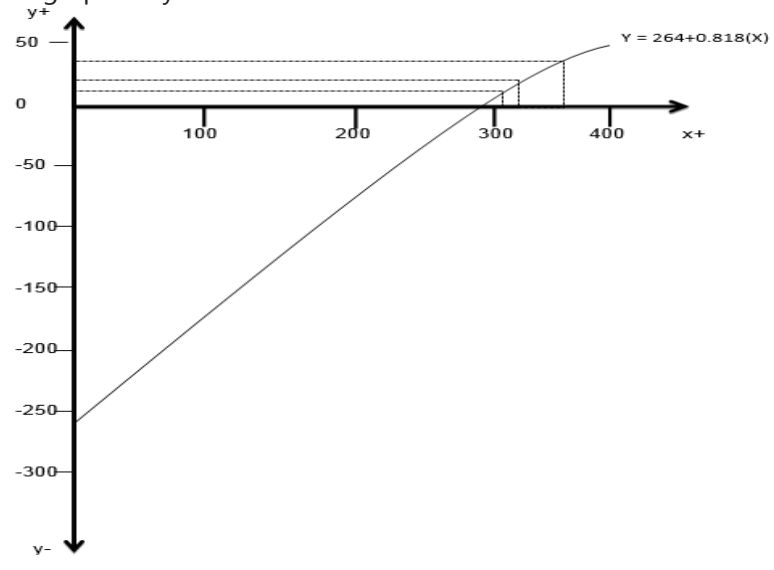

\section{Linear Regression Analysis of the Relationship between Growth in Farming Population and Land Depletion and Deforestation}

$\begin{array}{llllllllll}\mathrm{N} & \mathrm{a} & \mathrm{B} & \mathrm{ese}(\mathrm{b}) & \mathrm{r} & \mathrm{R}^{2} & \mathrm{t}_{\text {cal }} & \mathrm{df} & \text { Alpha } & \mathrm{t}_{\text {critical }} \\ 4 & -264 & .818 & .0098 & .9998 & .9996 & .8343 & 2 & .05 & 4.303\end{array}$

The table above shows that at 2 degrees of freedom (df) and 0.05 alpha levels of significance, the calculated value of $t$ is greater than the critical value of $t$ (i.e. $83.43>4.303$ ). Therefore, the null hypothesis $(H O)$ is rejected and the alternative hypothesis $(\mathrm{H} 1)$ accepted. This is to say that the data provide 99.96 per cent evidence that variation in land depletion and deforestation is caused by the growth in farming population. 